\title{
Evaluate the geological structure, petroleum potential by interpretation the 2D seismic data of Phu Quoc basin
}

- Kieu Nguyen Binh

Faculty of Technical Geology and Petroleum - Ho Chi Minh city University of Technology, VNUHCMC \& PVEP

- Nguyen Xuan Kha

- Ngo Thuong San

- Truong Quoc Thanh

- Thai Ba Ngoc

- Nguyen Xuan Huy

- Tran Van Xuan HCMC

Faculty of Technical Geology and Petroleum - Ho Chi Minh city University of Technology, VNU-

(Manuscript Received on August 10 ${ }^{\text {th }}$, 2015; Manuscript Revised on October $20^{\text {th }}$, 2015)

\begin{abstract}
So far, the understanding of Pre-Tertiary formations in the Phu Quoc basin is eliminated exploration strategy in the Phu Quoc area.Based on seismic data interpretation in block 42 of Phu Quoc Basin, the Isodepth maps were constructed by approach of conversingtime to depth from isochrone maps. The results of interpretation allowed to identify many seismic closures particularly on the isodepth map of the Brown section, but these closures are located deeply above $5000 \mathrm{~m}$, which reliability is fair and economic effect is weak. Hence, the Brown horizon did not considered as structures identified on and concentrate to describe those determined in the Orange and Purple horizons. Result of interpretation indicated 8 closures, which could be identified in the Orange and Purple horizons

seismic on the area of blocks 41-44 in order to get additional data for more precise evaluation
\end{abstract} of the petroleum potential and defining the

Keywords: 2D seismic, time-depth conversion, closures, isodepth, horizons. 


\section{INTRODUCTION}

Phu Quoc basin is considered as a Mesozoic basin developing on the Paleozoic basement and spread entirely on area of Blocks 41-44 which are located at the south of Phu Quoc island and stretched southward to offshore of West Viet Nam with area of $19.420 \mathrm{~km}^{2}$. Seismic data of these blocks are still few and limited only with $1087 \mathrm{~km}$ of 2D seismic lines MH-96 of grid 32 x $32 \mathrm{~km}[1,2,3,4,5]$. No exploratory well was drilled yet in surrounding area. Therefore, PetroVietnam assigned PVEP to perform acquisition of $2045 \mathrm{~km}$ of $2 \mathrm{D}$ seismic lines PQ-05 on the area of blocks 41- 44 in order to get additional data for more precise evaluation of the petroleum potential and defining the exploration strategy in the Phu Quoc area. [4,12]

Blocks 41-44 are located in offshore of
West Viet Nam at the south of Phu Quoc island (Fig.1).

The Phu Quoc basin is a forearc basin of Mesozoic age. It developed on the plate margin of an ancient Cratonic block - the Indosinia microplate, in contact with the Sibumasu microplate, both which are considered to be fragments that split from Gondwanaland during the Paleozoic Era. The basin is elongated meridionally with a width of $50 \mathrm{~km}$ and a length of more than $100 \mathrm{~km}$, and is covered by a Paleozoic-Mesozoic sediment complex of more than $8 \mathrm{~km}$ thickness at depocenters. [1, $6,7,8,9,10,11,12,13,14,15]$

\section{Methodology}

Based on the seismic data build up the appropriate maps, interpret the seismic profile, hence identify the potential closures

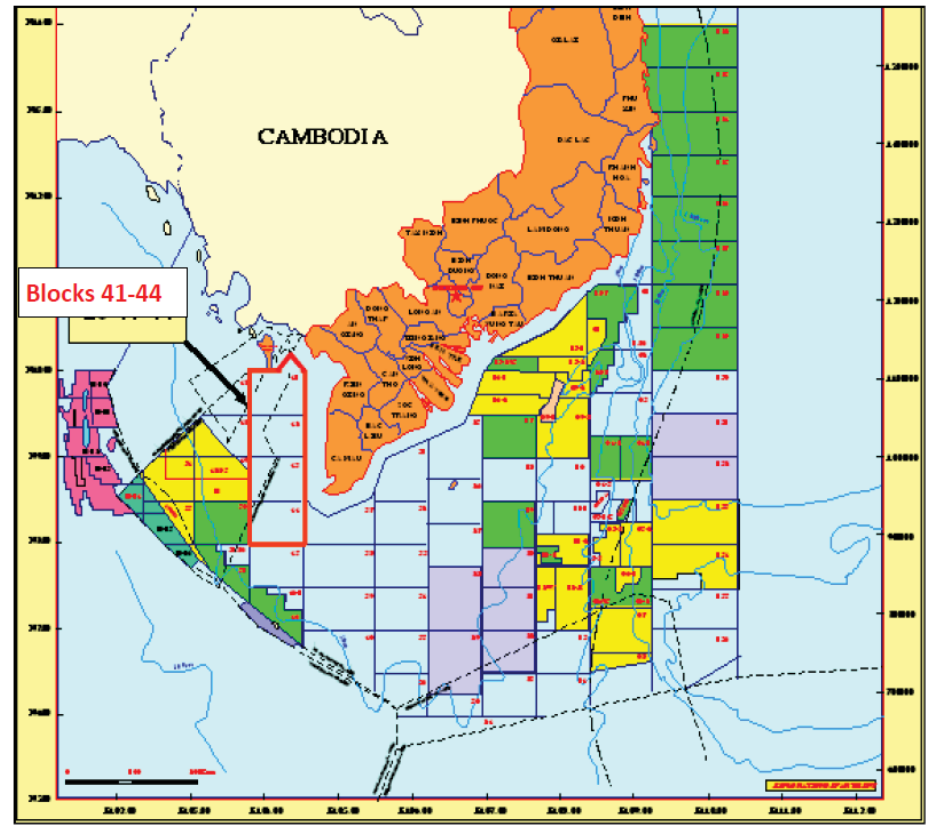

Figure 1. Location of studied blocks 
The report is performed on the base of following seismic data:

- Existed data includes $1087 \mathrm{~km}$ of 2D seismic of MH-96 with grid of $32 \times 32 \mathrm{~km}$ and $2045 \mathrm{~km}$ of 2D seismic acquisition of PQ-05 with grid $8 \times 8 \mathrm{~km}$ (Fig.3.1). Seismic data $\mathrm{MH}-$ 96 was acquired by Western Geophysical in 1996 and processed by Golden Pacific in 2000 with 8 seismic lines of $1087 \mathrm{~km}$.

In 2005 PVEP has performed the 2D seismic acquisition with $2.045 \mathrm{~km}$, which were processed later by Fairfield Viet Nam (the former Golden Pacific) in 2006 [4]

\section{Results and Discussion}

The seismic data quality it needs to remark that the reprocessed $1.087 \mathrm{~km}$ of $2 \mathrm{D}$ seismic lines "Minh Hải-96" at Golden Pacific center has a medium quality, while the $2.045 \mathrm{~km}$ of $2 \mathrm{D}$ seismic lines acquired in 2005 and reprocessed by Fairfield Việt Nam in 2006 are qualified very worse particularly in the eastern area with many diffractions and multiple reflectors (Fig.2; Fig.3)

[4].

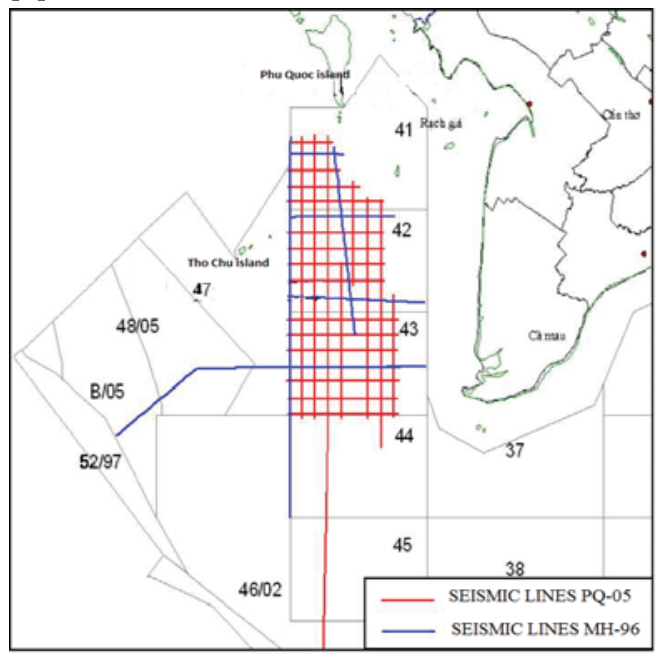

Figure 2. Location map of seismic profiles performed in blocks 41-44/Phú Quốc basin/

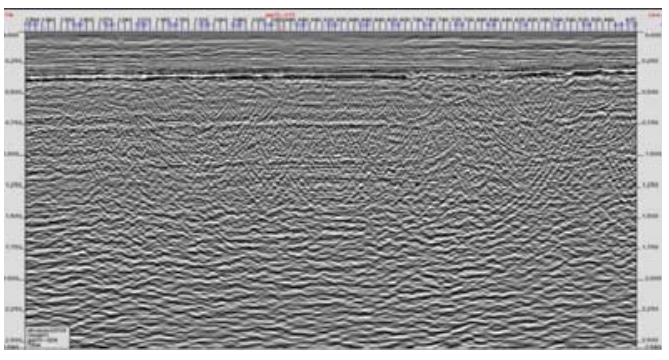

Figure 3. Seismic diffractions on line PQ05-028

\section{Correlation and Interpretation}

Based on existed 2D-seismic data (Fig. 2) and correlating with those from Malay - Tho Chu basin three (03) seismic markers were identified in the studied area including - the Orange, the Purple and the Brown markers. (Fig.4)

These boundaries are used in this report for correlation and interpretation. They coincide with those identified before by others authors in pre-existed reports.

The brown seismic marker: This marker characterizes the acoustic basement which is the deepest boundary enable to be observed on the seismic section. The brown marker is characterized by seismic reflectors of low amplitude and weak to very weak intensity. In some places the interpretation needs to draw by analogue with overlain horizons (Fig.4). The Brown horizon is identified as the basement of sedimentary basin and dated as Paleozoic (Devonian). It is the main study target of the project. The correlation reliability of the Brown horizon is quite low. 


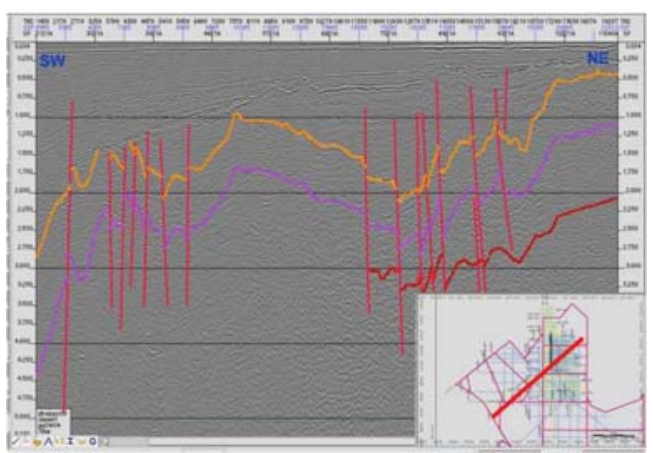

Figure 4. Seismic section correlating with Malay Tho Chu basin

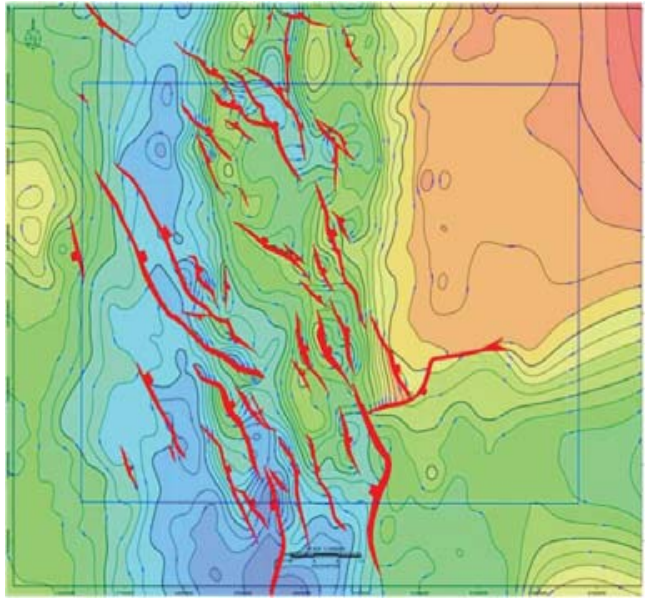

Figure 5. Isochrone map of the Orange section

Compiling of isochrone and isodepth maps with 1: 200,000 scale

All isochrones maps were constructed on software CPS3 Geoframe and illustrated on figures 5 for isochrones map of the Orange, Purple, and Brown sections. After converting to depths isodepth maps were constructed in scale of 1.200 .000 for all seismic boundaries using software CPS-3. Figures5 - 10 illustrated isodepths maps of the Orange, Purple, and Brown sections.

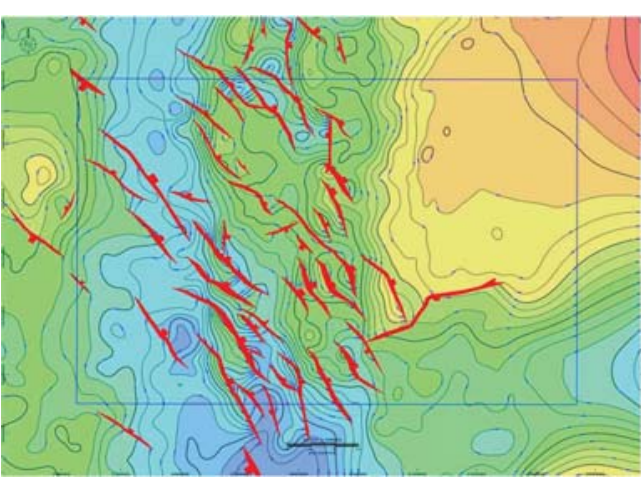

Figure 6. Isochrone map of the Purple section

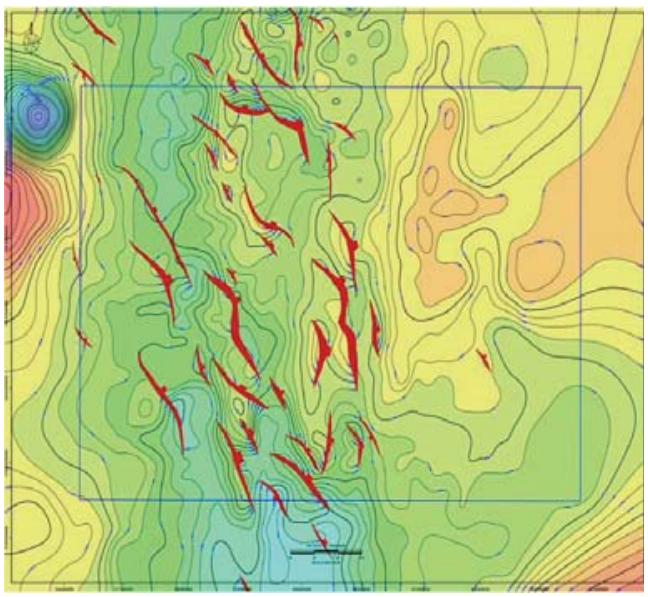

Figure 7. Isochrone map of the Brown section

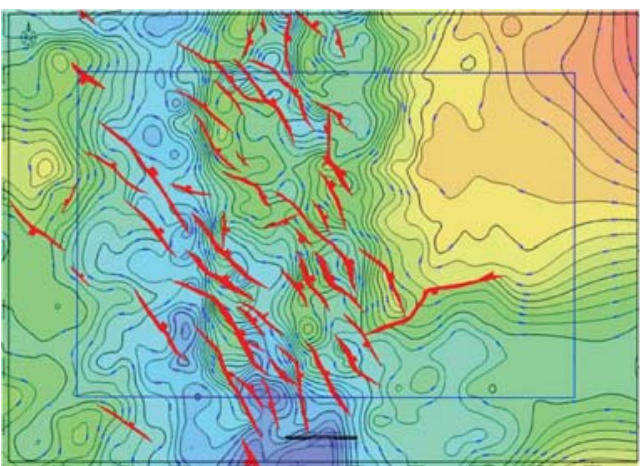

Figure 8. Isodepth map of the Purple section 


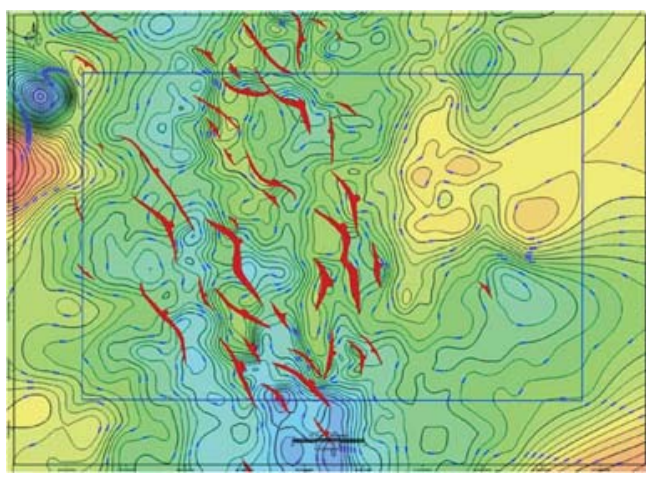

Figure 9. Isodepth map of the Brown section

Potential structures evaluation

Isodepth maps were constructed basing on the conversion Time to Depth method of isochrone maps. The result of interpretation allowed to identify many seismic closures particularly on the isodepth map of the Brown section but these closures are located deeply above $5,000 \mathrm{~m}$, which reliability is fair and economic effect is weak. So, we did not consider structures identified on the Brown horizon and concentrate to describe those determined in the Orange and Purple horizons. Result of interpretation indicated 8 closures, which could be identified in the Orange and Purple horizons and numbered from $\mathrm{N}^{0} 01$ - to $\mathrm{N}^{0} 08$ (Fig.11).

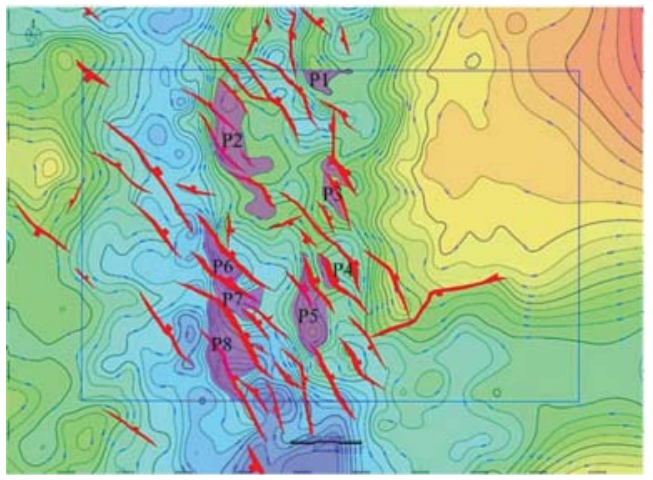

Figure 10. Potential structures identified on Purple horizon /Block 42/

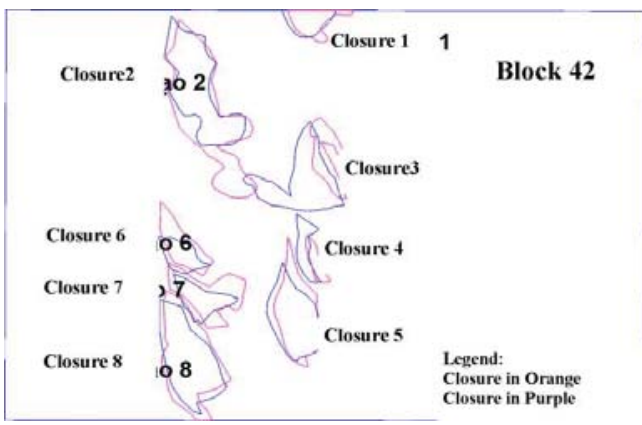

Figure 11. Potential structures in block 42

Structure/Closure 01:

Located westerly of block 42 Structure 01 represents a 3-way dip closure closed to fault. Top of structure and most of structure area lay in block 41. Structure 01 is identified on both horizons- the Orange and the Purple. On the Orange horizon top of structure is drawn at $1800 \mathrm{~m}$ depth, with largest closure at $2450 \mathrm{~m}$ and area of $14,1 \mathrm{~km}^{2}$. On the Purple horizon the structure top is located at $3,600 \mathrm{~m}$ depth, with largest closure at $4,000 \mathrm{~m}$ and area of $15,72 \mathrm{~km}^{2}$ (Fig. 11, 12; 13).

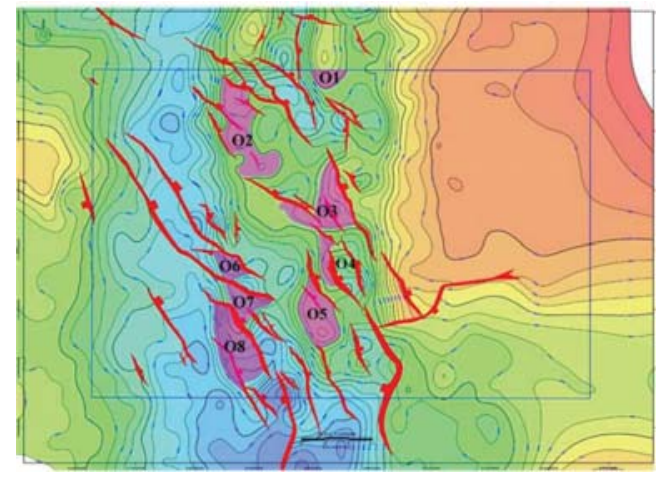

Figure 12. Potential structures identified on Orange horizon /Block 42/ 


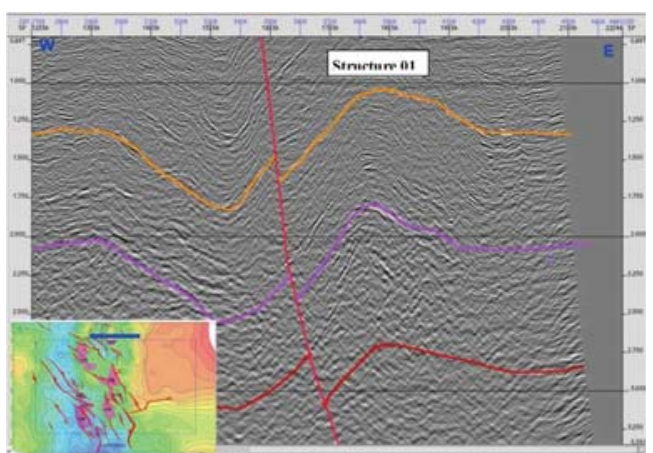

Figure 13. Seismic section cross the structure 01

\section{Structure/ Closure 02}

The structure 02 is located in NW of block 42. and represented as an anticline intersected by fault system of NW - SE direction. The anticline is closed on both horizons Orange and Purple. The top of structure on the Orange horizon is drawn at $2,000 \mathrm{~m}$ depth with largest closure at $2,350 \mathrm{~m}$ and area of $68.81 \mathrm{~km}^{2}$. The top of structure on Purple horizon lay at $3,400 \mathrm{~m}$ with largest closure at $3.800 \mathrm{~m}$ and area of $95.36 \mathrm{~km}^{2}$ (Fig. 11; 12; 14);

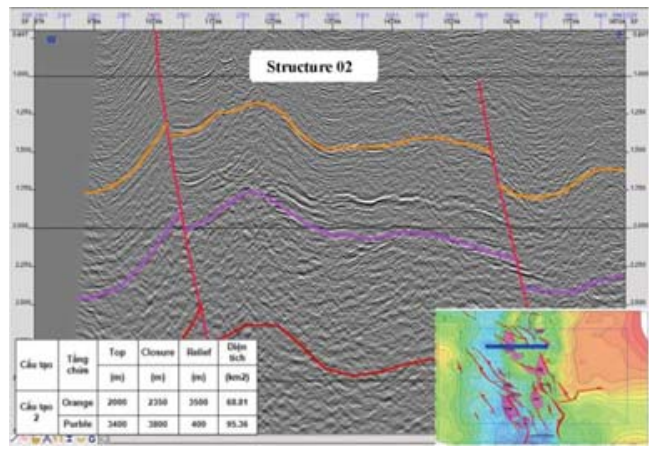

Figure 14. Seismic section cross structure 02

\section{Structure/ Closure 3}

Structure 03 locates nearly the Central Uplifted Zone of Phu Quốc basin and at the center of block 42. Structure represents an anticline of 3- way dip closure cut by fault system of NW-SE trend. Anticline is closed to fault and identified on both horizons - the Orange and Purple. On the Orange horizon, the structure top is drawn at $1,800 \mathrm{~m}$ depth, and the largest closure is at $2,250 \mathrm{~m}$ with area of 51.29 $\mathrm{km}^{2}$. On the Purple horizon the top of structure is located at 3,400 and the largest closure is at $3,600 \mathrm{~m}$ with area of $19.63 \mathrm{~km}^{2}$. (Fig. 11; 12; $15)$;

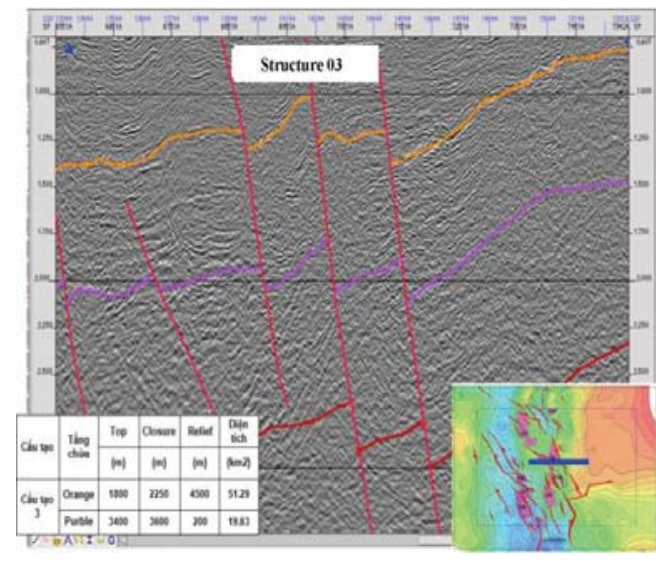

Figure 15. Seismic section cross structure 03

\section{Structure / Closure 4}

Structure 04 locates at the center of block 42 and southward of structure 03. It represents an anticline closed to fault with 3-way dip closure. The closure is identified on both horizons Orange and Purple. On the Orange horizon the structure top is drawn at $2,000 \mathrm{~m}$ depth with largest closure at $2,300 \mathrm{~m}$ and area of $12.08 \mathrm{~km}^{2}$. On the Purple horizon the top of structure is located at $3,600 \mathrm{~m}$ with largest closure at $3,800 \mathrm{~m}$ and area of $6.25 \mathrm{~km}^{2}$ (Fig.11; $12 ; 16)$.

\section{Structure / Closure 05}

Structure 05 locates southward of block 42 and northward of the southern trough of Phu Quốc basin. The structure represents an anticline of 3-way dip closure cut by fault system of NWSE direction and closed to fault. It is identified 
as anticline closure on both horizons - the Orange and Purple. The top of closure on the Orange horizon is drawn at $2,000 \mathrm{~m}$ depth with largest area of $49.32 \mathrm{~km}^{2}$ at $2,400 \mathrm{~m}$ depth. On the Purple horizon the top of structure is at $3,600 \mathrm{~m}$ depth, with largest closure at $4100 \mathrm{~m}$ depth of $50.26 \mathrm{~km}^{2}$ (Fig. 11; 12; 17).

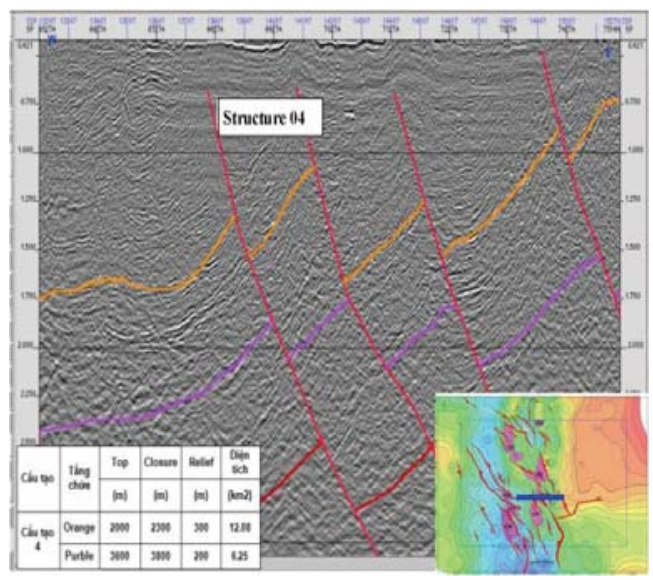

Figure 16. Seismic section cross structure 04

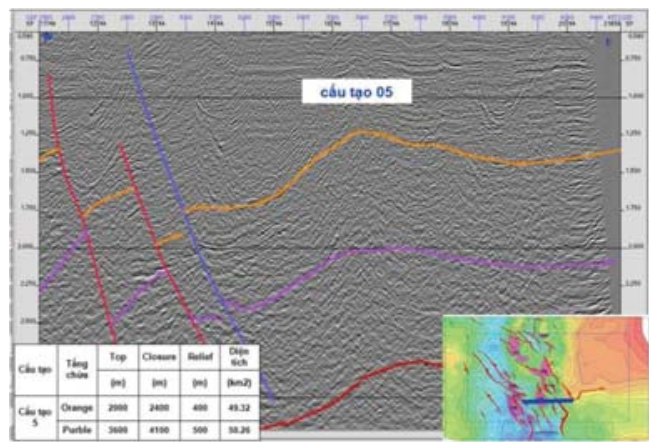

Figure 17. Seismic section cross structure 05

\section{Structure / Closure 06}

Structure 06 is located nearly the center of block 42 and closely to the Western trough at NW. It represents an anticline of 2-way dip closure cut by fault system. This anticline is closed to fault and determined on both horizons - the Orange and the Purple. The top of structure is determined on the Orange horizon at $2,600 \mathrm{~m}$ depth with largest closure at $3,200 \mathrm{~m}$ and area of $15.46 \mathrm{~km}^{2}$. On the Purple horizon the top of structure is drawn at $4,200 \mathrm{~m}$ with largest closure at $5,000 \mathrm{~m}$ and area of $24.58 \mathrm{~km}^{2}$ (Fig. 11; 12; $18)$.

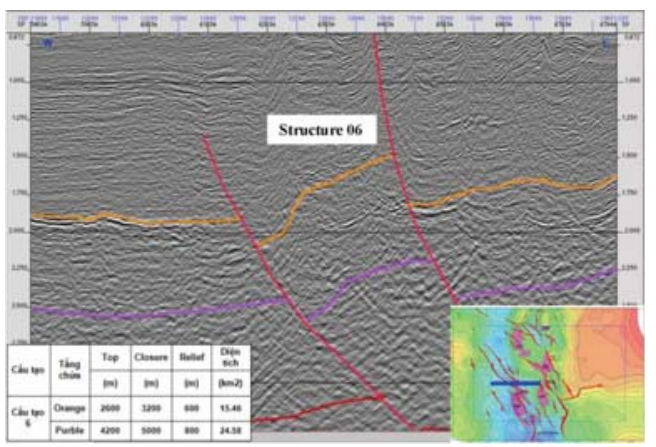

Figure 18. Seismic section cross structure 06

\section{Structure / Closure 07}

The structure 07 locates at the south of structure 06 closely to the Western trough of Phú Quốc basin. The structure has anticline form cut by a fault system of NW-SE direction. It is a 2-way dip closure and closed to fault. Structure is identified on both horizons - Orange and Purple. On the Orange horizon the top of structure is determined at $2,400 \mathrm{~m}$ depth with largest closure at $2,900 \mathrm{~m}$ and area of $21.28 \mathrm{~km}^{2}$. On the Purple horizon the structure top is drawn at $4,200 \mathrm{~m}$ depth with largest area of closure of $27.24 \mathrm{~km}^{2}$ at $4,200 \mathrm{~m}$. (Fig. 11; 12; 19)

\section{Structure / Closure 08}

The structure 08 is located southerly of block 42, and bounded northwesterly by the Western trough and by the Southern trough of Phú Quốc basin at the south. It represents an anticline closed to fault in form of 2-way dip closure. Structure is identified on both horizonsthe Orange and Purple. On the Orange horizon the top of structure is determined at $2,200 \mathrm{~m}$ 
depth; the largest closure of $63.8 \mathrm{~km}^{2}$ is at $3,400 \mathrm{~m}$ depth. On the Purple horizon the structure top locates at $3,600 \mathrm{~m}$ with largest closure at $5,000 \mathrm{~m}$ depth and area of $74.79 \mathrm{~km}^{2}$ (Fig. 11; 12; 20).

\section{Conclusions}

Although seismic data quality is not good enough, seismic interpretation 03 floors showed geological structure of block 42 to the direction of the main structure is dominated by fault system western north-east south:

- There are 08 sedimentary structure have been discovered in Paleozoic period.

- The potential reserves are preliminary assessment for block 42 was about 1,999 bbcf gas or 1036 MMstb oil in place (P50).

- Coefficient of success of08 structures(POS) POS $=0.154$ have been appreciated over structures remaining in the area $(\mathrm{POS}=0: 12$ to $0: 14)$.

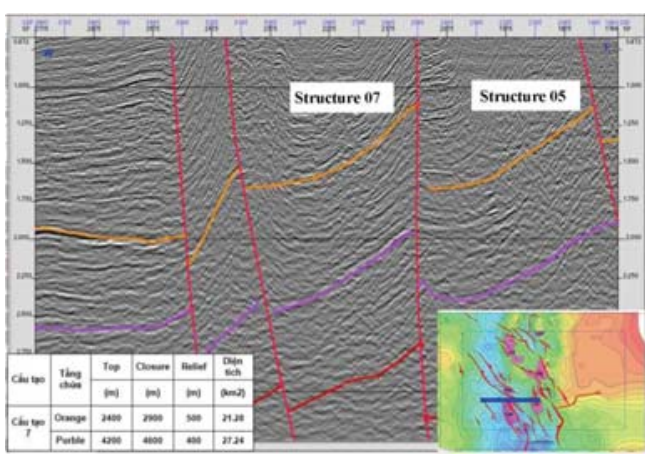

Figure 19. Seismic section cross structure 07

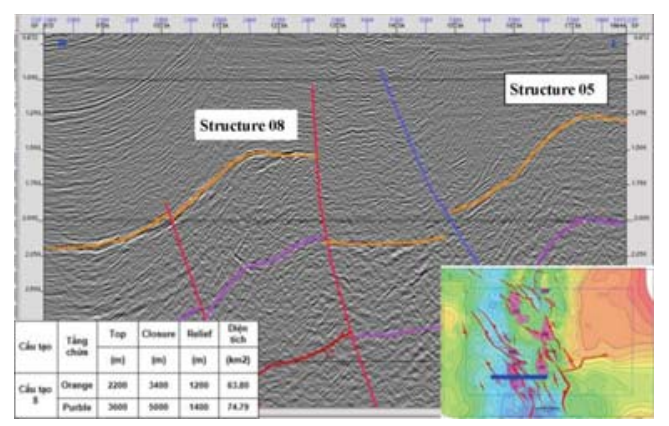

Figure 20. Seismic section cross structure 08 


\section{Đánh giá cấu trúc địa chất dầu khí, tiềm năng dầu khí bằng tài liệu địa chấn $2 \mathrm{D}$ trên bể Phú Quốc}

- Kiều Nguyên Bình

Khoa Kỹ thuật Địa chất \& Dầu khí - Trường Đại học Bách khoa Tp.HCM \& PVEP

- Ngô Thường San

- Nguyên Xuân Khá

- Trương Quốc Thanh

- Thái Bá Ngọc

- Nguyễn Xuân Huy

- Trần Văn Xuân

Khoa Kỹ thuật Địa chất \& Dầu khí - Trường Đại học Bách khoa, ĐHQG-HCM

\section{TÓM TẮT}

Đến thời điểm hiện tại, sự hiểu biết của các thành hệ truơóc Đệ Tam trong bể Phú Quốc rất hạn chế do thiếu tài liệu khoan và sự vắng mặt của điểm vết lộ trù trên đảo Phú Quốc và một số hòn đảo nhỏ khác. Bằng phương pháp twơng tụ với địa tầng tù các khu vục xung quanh, ranh giới địa chấn có thể liên kết tới tuổi địa tầng. Đất đá tuổi tiền Cambri và tuổi Paleozoi sóm tuy chua được phát hiện trong khu vưcTây -Nam Việt Nam nhung bằng phuoong pháp tuoong tưđối sánh có thể dư đoán bao gồm các đá biến chất nhu phylite chloritized, đá phiến sericit, đá thạch anh và kẹp với đá siêu ba zo. Do đó, khi được tập đoàn dầu khí giao giao nhiệm vu, PVEP đã triển khai thu thập dũ liệu địa chấn $2 D$ trên diện tích lô 41.44 để bổ sung dũ liệu nhằm đánh giá chính xác hơn tiềm năng dầu khí và xác định chiến lược thăm dò trong khu vục bể Phú Quốc. Trên co sở kết quả minh giải địa chấn 2D lô 42 của bể Phú Quốc đã thiết lập bản đồ đẳng sâu dựa trên mô hình chuyển đổi thời gian sang chiều sâu của bản đồ đẳng thời gian. Kết quả của việc minh giải cho phép xác định nhiều cấu trúc đóng, đặc biệt trên bản đồ đẳng sâuranh giới màu nâu, nhung nhũng cấu tạo khép kín này nằm sâu trên $5.000 \mathrm{~m}$, do đó độ tin cậy và khả năng đánh giá hiệu quả kinh tế thấp. Vì vậy, cấu trúc này đã không được xem xét mà tập trung để mô tả nhũng cấu trúc được xác định trong ranh giới cam và ranh giói tím. Kết quả minh giải cho thấytrong khu vục nghiên cưu bao gồm 8 cấu tạo khép kín.

Tù khóa: Địa chấn 2D, chuyển đổi thời gian-độ sâu, khép kín, đẳng sâu, mặt phản xạ. 


\section{REFERENCES}

[1]. Bùi Phú Mỹ, Trần Hồng Lĩnh, "Tuổi địa chất và phân loại địa tầng các trầm tích lục địa ở đảo Phú Quốc, Thổ Chu và An Thới, tỉnh Kiên Giang", Liên đoàn Bản đồ địa chất miền Nam, 2005, Tp. HCM.

[2]. Vũ Khúc và nnk, "Từ điển các phân vị địa tầng Việt Nam", Cục Địa chất khoáng sản Việt Nam, 2000, Hà Nội.

[3]. Tống Duy Thanh và nnk. "Các phân vị địa tầng Việt Nam", nhà xuất bản Đại học Quốc gia Hà Nội, 2005, Hà Nội.

[4]. Báo cáo đánh giá tiềm năng dầu khí khu vực Phú Quốc, Công ty Thăm dò Khai thác dầu khí, 2000, Tp. HCM.

[5]. Nhóm nghiên cứu Đông Nam Á, "Xây dựng lại lịch sử kiến tạo Đông Nam Á từ 50 triệu năm đến nay", Đại học Tổng hợp London, 1995, Anh.

[6]. Báo cáo thực địa năm 2005, Công ty Thăm dò Khai thác dầu khí, 2005, Tp. HCM.

[7]. Báo cáo phân tích cổ sinh các mẫu thực địa Phú Quốc, Viện Dầu khí Việt Nam, 2005.

[8]. Báo cáo phân tích cổ sinh các mẫu thực địa Phú Quốc, CoreLab Indonesia, 2005.

[9]. Báo cáo phân tích cơ lý các mẫu thực địa Phú Quốc, Viện Dầu khí Việt Nam, 2005.

[10]. Báo cáo phân tích địa hóa các mẫu thực địa Phú Quốc, Viện Dầu khí Việt Nam, 2005.
[11].Báo cáo phân tích thạch học các mẫu thực địa Phú Quốc, Viện Dầu khí Việt Nam, 2005.

[12].Surawit Pradidtan, "Thăm dò dầu khí vùng Đông bắc Thái Lan: kết quả và tiềm năng", Hội nghị quốc tế về địa chất, địa kỹ thuật và tài nguyên khoáng sản của Đông Dương, 22-25/11/1995, Khon Kaen, Thái Lan.

[13].Racey A., và nnk, "Địa tầng và tiềm năng chứa của nhóm Khorat Group tuổi Mesozoi, Đông bắc Thái Lan - phần 1: lịch sử phát triển địa tầng và trầm tích", Tạp chí Địa chất Dầu khí, volume 19(1), 1/1996, trang 5-40.

[14].Canham A. C., và nnk, "Địa tầng và tiềm năng chứa của nhóm Khorat Group tuổi Mesozoi, Đông bắc Thái Lan - phần 2: quá trình thành đá và chất lương vỉa chứa", Tạp chí Địa chất Dầu khí, volume 19(3), 1/1996, trang 321-338.

[15].Paul F. Lovatt Smith, Robert B. Stokes, Charlie Bristow, Andrew Carter, "Nghịch đảo kiến tạo giữa Creta ở đông bắc địa khối Khorat thuộc Lào và Thái Lan", Lịch sử kiến tạo Đông Nam Á, ấn bản đặc biệt số 106 của Hội Địa chất, 1996, London, trang 233-246. 